\section{A A}

\author{
or
}

\section{HOSPITAL PRACTICE, BRITISH AND FOREIGN.}

Fulla autem est alia pro certo noscendi via, nisi quamplurimas et morborum et dissectionum historias, tum aliorum tum proprias eollectas habere, et inter se comparare.-MorgagNI De Sed. et Caus. rorb., lib. iv. Procemium.

\section{SALFORD ROYAL HOSPITAL.}

TWO CASES OF GANGRENOUS STRANGULATED HERNIA; RESECTION OF BOWEL; RECOVERY IN ONE CASE.

(Under the care of Mr. EDMUND T. MLLAER )

CASES of strangulated hernia which have become gangrenous are fortunately now more rare than in former years, and as intestinal anastomosis by the aid of Murphy's button is still on its trial a record of its application to this class of case may be deemed to be sufficiently interesting for publication.

CASE 1.-A single woman, aged forty years, the subject of phthisis. was admitted into the Salford Royal Hospital on June $23 \mathrm{rd}$, 1897, suffering from a strangulated femoral hernia on the right side. She stated that she had bad a capture for three or four years, that for many months it tad not been entirely reduced (? lymphatic glands), but that she had worn a truss over it. There had not been an action of the bowels for seven days, and vomiting had persisted for five days, becoming stercoraceous two or three days before her admission. The patient had rather a languid look, the palse was intermittent but otherwise fairly good, and the skin of the groin covering the hernia had assumed a greenish-yellow colour. Under chloroform herniotomy was performed. On opening the sac it was found to contain notbing but a loop of small intestine measuring from four to five inches, the middle half of which had sloughed through its entire thickness, but had not actually perforated. After freeing the constriction the loop of gut was drawn down a little, and in order to prevent escape of freces a double cord passed through the mesentery was divided, and each tube of intestine firmly ligatured just beyond the seat of strangulation, thus securing healthy bowel for these temporary clamps. The herniated bowel was then cut off below the two ligatures and the two stumps of intestine were well washed. The opening into the abdomen was now enlarged by extending the incision upwards for an inch or more, Poupart's ligament of course being divided. A medium sized Murphy's button was selected. The distal (collapsed) stump was dealt with first. Its end with the ligature was re-amputated, the half button was inserted, and its central tube was tied in the lumen of the intestine, just as one would tie a tube in the month of a bag. The proximal (distended) stump was similarly treated after emptying and temporarily clamping the intestine a few inches higher up; the two segments of the button were then pressed home. At this stage it was discovered that the cord securing the male half of the button had been inadvertently tied round the spring flange or buffer-segment instead of round the central cylinder, so that the silk cord interfered with a good apposition of the serous surfaces; a continuous Lembert's suture was therefore inserted beyond the line of junction of the approximated buttons, and lastly the edges of the cut mesentery were united. After closing and dressing the wound the patient's stomach was washed out. Feeding with diluted milk (in tablespoonful doses) was commenced six hours after the operation. The button was not passed till the forty eighth day, the silk cords still retaining remnants of the annular sloughs. The patient made an uninterrupted recovery so far as the operation was concerned, and that in spite of the fact that the phthisis was accompanied by a troublesome cough with the daily expectoration of from six to eight ounces of nummular sputum. She was discharged from hospital on Sept. 23rd, having been kept in the last morth on account of her lung trouble.

CASE 2.-A married woman, aged fifty-one years, was admitted on July $7 \mathrm{th}, 1897$, just a fortnight after the first case, suffering from a strangulated inguinal hernia, with gangrene of all structures even to the skin; the egg-shaped rupture occupied the left labium and measured about seven inches by four inches. There was a history of vomiting and obstruction commencing ten days previously, but so reticent bad the patient been that it was left for a district nurse to discover a large tumour of the labium, which was already black from gangrene. On admission to hospital the woman was hardly coherent, and her condition was desperate. Under ether the hervial sac was opened, washed out, and the macerated slough of small intestine, measuring ten or twelve inches, removed ; the emerging and returning gut were temporarily ligatured as in Case 1 , whilst all the gangrenous tissue--sac, skin, \&c.-was dissected away. The largestsized button was chosen and fixed as before, after allowing the distended bowel to empty itself. The woman rallied for a while, but died early the next morning (about six hours after the operation) from exhaustion.

Necropsy.-The post-mortem examination showed very good repair for the time and a healthy peritoneum; the bowel at the seat of resection readily withstood a pressure of from two to three feet of water without leakage.

Remarks by Mr. MILNER.-The introduction of a ready means of establishing intestinal anastomosis has been an important factor in determining the surgery of gangrenous strangulated hernia. It was formerly a common practice in such cases to be content in the first instance with relieving the obstruction, and to hope that the patient's condition would improve before resorting to a secondary operation for the cure of the inevitable fæcal fistula. Experience has shown that only a small proportion of such cases survive to undergo the second operation, for even of those who recover from the immediate effects of prolonged strangulation many gradually succumb to inanition, especially if the alimentary canal has been cut short high up in the small intestine, so that any readier method of restoring the continuity of the alimentary canal is welcomed which can be effected at the time of the herniotomy, and especially if the operation can be accomplished without skilled help. Daring both the above operations the senior house surgeon happened to be out, and the junior house surgeon, Dr. Arnison, was fully occupied, especially in the second case, in giving the anæsthetic, so that I had to do the operations single-handed but for some valuable help from the nurses. This was my reason for departing from the more usual method of securing the buttons and adopting what appeared to me at the time the quickest though perhaps more clumsy plan. Still, under ordinary circumstances I would not recommend it, as in both cases I found it necessary to supplement the operation with Lembert's sutures, though in the second case merely to cover in a little exposed mucous membrane near the mesentery. The temporary ligaturing of the bowel I found of great assistance; it enabled me to cut away rapidly the gangrenous portions and to cleanse thoroughly the parts before enlarging the abdominal wound, thus minimising the risk of infecting the peritoneum. In the successful case it is interesting to note that the intermission of the pulse-probably due to toxins-disappeared about the third day. The healing of Poupart's ligament has resulted in a thoroughly firm and sound cicatrix, and the bowels, though at first rather constipated, have since become normal.

\section{ROYAL INFIRMARY, NEWCASTLE-UPON-} TYNE.

A SUCCESSFUL CASE OF PYLORECTOMY.

(Under the care of Dr. G. H. HUME.)

THE operation of resection of the pyloric end of the stomach for malignant disease must always remain one of the most severe operations in surgery. The amount of shock is great and much care is required to bring accurately together the very unequal apertures of the stomach and the duodenum. The recorded mortality is high as might have been expected. Winslow ${ }^{1}$ collected 55 cases and of these 41 died from the effects of the operation, a mortality of 74.5 per cent. ; Bramer $^{2}$ collected 72 cases of pylorectomy and 55 died, a death-rate of 76.3 per cent. ; in Eiselsberg's list of 19 cases from Billroth's clinic from 1885 to 1889 there were 10 deaths : this is equal to a mortality of 52 per cent. ${ }^{3}$ Even should the patient survive the immediate cangers of the operation the prospect of a perfect recovery is exceedingly small. In a large majority of the cases recurrence occurs after a few

1 American Journal of the Medical Sciences, 1885, vol. Ixxxix., p. 345. Centralhat fur Chirurgie, 1885, p. 58. 